\title{
"Writing the Other as Other": Exploring the Othered Lens in Academia Using Collaborative Autoethnography
}

\author{
Ahmed Ajil ${ }^{1}$ \& Kwan-Lamar Blount-Hill ${ }^{2}$
}

\begin{abstract}
Trends seemingly signal the decay of White heterosexual male hegemony in academia. Still, while changes have addressed lack of access to an academic system whose benefits are assumed, critical literature calls into question Western-based theory and traditionally Eurocentric ways of knowledge production. An important programmatic component of decolonizing knowledge production consists of arguing for increased inclusivity and diversity among scholars. The present study is inscribed in these decolonial tendencies and focuses on the experience of otherness inside academia. Using collaborative autoethnography, we set side-by-side the academic and professional experiences and epistemological reflections of two criminal justice and criminology scholars: an Arab European scholar of politicoideological violence and a Black American scholar of identity and the psychology of justice. We explore otherness as a 'social fact' and identify three dimensions, namely (1) otherness as a lens to read coloniality, (2) feeling and coping with otherness, and (3) otherness as connection. We suggest that promoting the "othered lens" in academia, especially criminology, may not only be healthy and necessary for diversifying views and perspectives but may also be epistemologically and methodologically vital for how criminology engages with the socially deviant or harmed Other who it is, by its very essence, preoccupied with.
\end{abstract}

Keywords: decolonisation, otherness, identity, autoethnography, narrative

\footnotetext{
${ }^{1}$ School of Criminal Justice, University of Lausanne, Switzerland

${ }^{2}$ Kings County District Attorney's Office, Brooklyn, NY, USA
} 


\section{Introduction: Who Produces Knowledge?}

The academic industry is one of the most powerful actors in the social and political sphere for it produces discourse, i.e. a system of thoughts, ideas, concepts, theories, and practices that provide a particular view and understanding of the world (Deckert, 2014; Keet, 2014; Said, 1978). Discourse generates forms of political, intellectual, moral and cultural power ${ }^{\mathrm{i}}$ (Said, 1978) with real-life repercussions. As Hall (1997) argues: "It may not be true that single parenting inevitably leads to delinquency and crime. But if everyone believes it to be so, and punishes single parents accordingly, this [...] will become 'true' in terms of its real effects" (p. 49).

Knowledge construction is, thus, closely tied to power relations (Foucault, 1980). The power of academic knowledge warrants a thorough and continuous examination of who is producing academic discourse. Leading voices in academia - in criminology especially - are still predominantly White, heterosexual, male, Eurocentric and status-quo oriented. Noting its historical use by colonial administrators to control the 'criminal' working class, Kitossa (2012) argues that criminology was "a handmaid of colonialism from its inception" (p. 204). Promiscuity between research on deviance and crime and the policies and practices of crime control (Garland, 2011) suggests a continuation of this tendency and a need to examine who contributes to criminology and to what degree their contributions reflect colonial logics.

As the academic universe becomes increasingly diverse, we are witnessing the emergence of critical perspectives from the inside that challenge largely Eurocentric and hegemonic dynamics in the system of knowledge production. Decolonial perspectives have recently entered academic debates, calling for epistemological decolonization, including critical engagement with the heritage of White Anglo-European hegemonic thinking in present criminal justice practice. In criminology and criminal justice, several have focused on decolonizing a field historically shaped by imperialist aspirations to control the colonized abroad but also at the heart of the Western metropolis (Agozino, 2004). Decolonial perspectives in criminology take a critical standpoint towards mainstream criminology and its instrumentalization for imperialist and neo-colonialist agendas (Agozino, 2004; Cain, 2000; Covington, 1995; Cunneen, 2011; Deckert, 2014; Tatum, 2000; Tauri, 2012). An important aspect of decolonization focuses on the inclusion of voices from the periphery and the Global South, and the 
decentralization and 'indigenization' of knowledge production, merging with calls for "minority perspectives" (Belknap, 2015; Garcia, 2018; Moosavi, 2018; Phillips \& Bowling, 2003; Russell, 1992; Takagi, 1981).

Kitossa (2012) suggests inquiry into "the experiences of criminologists 'of colour'" (p. 206). In the following work, we engage with the notion of otherness in academia and analyse our academic and professional experiences and epistemological reflections as doctoral students of criminal justice and criminology. In a searching comparative and dialogic autoethnographic examination, we explore our multiple othered identities (race, religion, nationality, sexuality, epistemology, methodology, practitioner, etc.) and the plural ways in which they shape our experience working in academia and beyond. In The Prison Notebooks, Gramsci wrote that

the starting point of critical elaboration is the consciousness of what one really is, and is 'knowing thyself' as a product of the historical processes to date, which has deposited in you an infinity of traces, without leaving an inventory. Therefore, it is imperative at the outset to create such an inventory (Gramsci, 1971, p. 628; last sentence quoted by Said, 1978, p. 25).

The challenging introspective process of collaborative autoethnography is an important component of exploring our epistemological positionality within academia and beyond. To understand how we are shaped by our otherness, how we engage with it and how it may both hamper and promote our work as researchers, an in-depth investigation seems crucial and may be a first step to what Fanon (1968) describes as "the creation of new men" (p. 36) through decolonization. We hope to encourage other researchers in this pursuit.

Through a series of guided and interactive reflections composed over four weeks and systematically analysed, we identified several transversal themes connecting our experiences in very distinct (though both Western) contexts. We found evidence of an 'othered lens' which we characterize as a heightened sensitivity to hegemonic/status-quo biases and the impact of research that ignores the voices of those it purports to study. In what follows, we position our piece within the broader literature on decolonization, reviewing the work of our forebears. We then explain the process from which we derive our findings, present those findings and conclude by discussing 
the meaning of this work, recognizing both its limitations and its promise in furthering current understandings, future research and ongoing scholaractivism.

\section{Decolonial Perspectives in the Social Sciences and Criminology}

Since the millennial turn, there has been a continuous increase in articles on decolonization, both generally (see Figure 1) and in criminology (see Figure 2). A Web of Science search reveals a slowly increasing number of works produced between 2000 and 2010, though remaining less than 50\% per year in criminology. The last three years have seen much higher numbers: 160 articles in 2017, 238 in 2018, and 243 in 2019, in line with a general trend across disciplines.

Figure 1. Web of Science results for "decolonization", 2000-2019

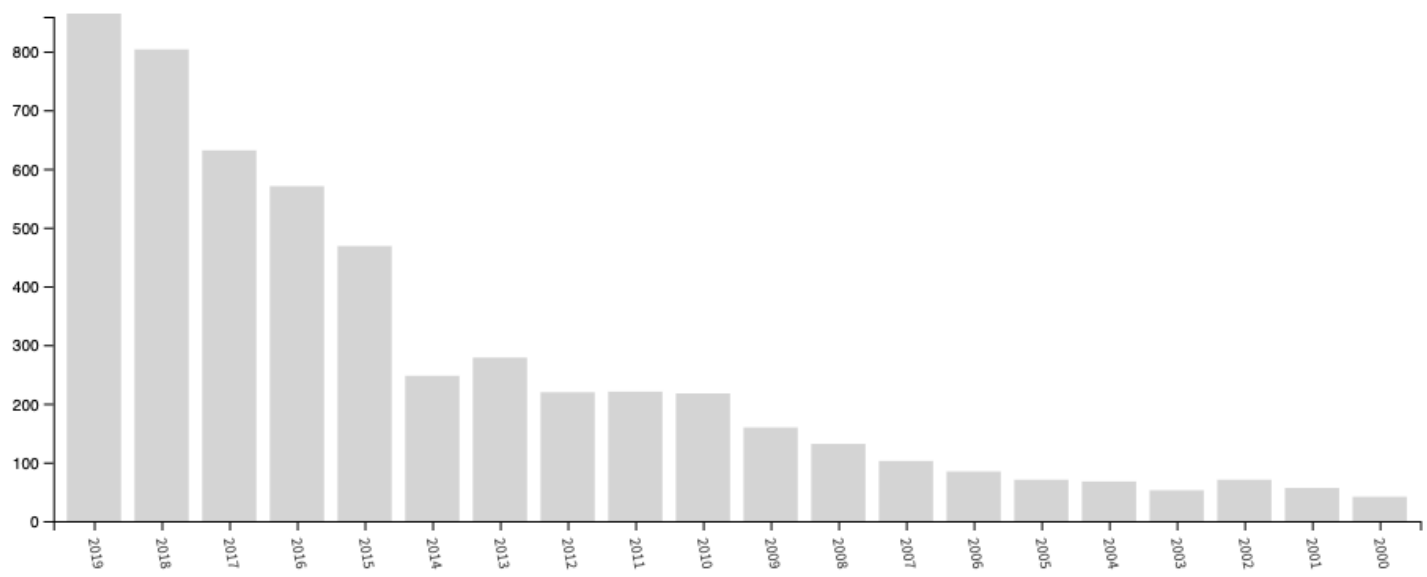

Figure 2. Web of Science results for "decolonization" AND "criminology", 2000-2019

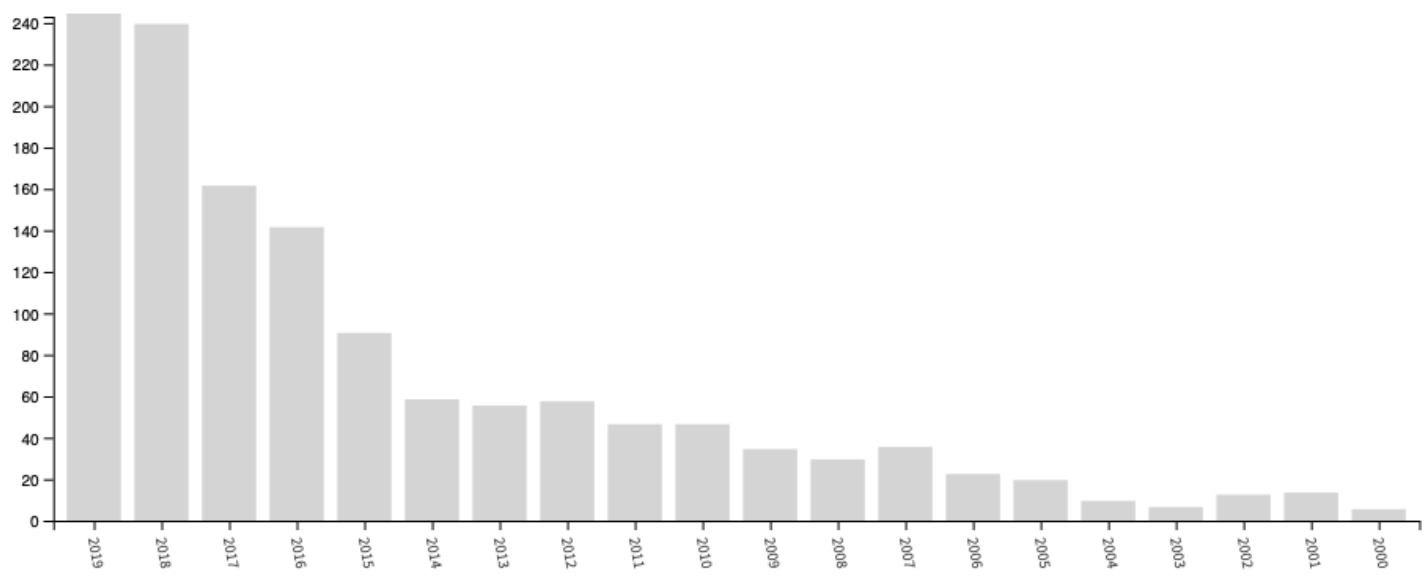


Decolonization describes the "undoing of colonialism" by granting former colonies independence and self-governance, largely occurring from the middle of the last century for most colonized countries (Blount-Hill, 2019).ii Beyond this political and historical process, decolonial perspectives warn that the "colonial matrix of power" has far from disappeared (Mignolo, 2011; Quijano, 2007). Even after the end of direct sovereign control over many foreign territories, the ideologies and power structures that justified and maintained colonial projects continue to impact peoples in and from the Global South, perpetuating dynamics of oppression (Keet, 2014; Mignolo, 2005; Quijano, 2007). The decolonial project thus includes highlighting how academia serves colonial oppression (Agozino, 2003; Al-Kassimi, 2018; Bull, 2004; Keet, 2014). Agozino (2003) insists on a sound analysis of how criminological knowledge was put at the service of imperialist projects and how imperialist thinking patterns persist in criminological scholarship (see also Cunneen, 1999). He suggests the need for a decolonial or countercolonial criminology, a "theory of social control from the point of view of antiimperialist scholars who are familiar with the history of resistance to colonialist (including the colonial, post-colonial, neo-colonial, internalcolonial and re-colonial) law and order reasoning" (Agozino, 2004, p. 350).

Decolonial 'thinking and doing' highlights, questions, resists and fights this matrix of power on political, economic, social and epistemic levels (Keet, 2014), which includes, as Wa Thiong'o (1986) famously called for, a Decolonisation of the Mind. Western social theory, including criminology, claims to be context-free, post-ideological, and, therefore, universal. Yet, the heavily Western situatedness of criminology - drawing predominantly on the theoretical, research and analytical preferences of privileged individuals from a restricted geopolitical context - as well as its heavily masculinized configuration raise strong doubts about its universality (Aas, 2012; Moosavi, 2018; Stockdale \& Sweeney, 2019). Decolonising criminology thus requires a more honest engagement with non-Western scholarship (Moosavi, 2018) as well as greater inclusivity of marginalized voices in higher education (e.g. Arday \& Mirza, 2018; Hinton-Smith, 2012). Within the Global North, decolonial projects become aligned with calls to promote the 'othered lens'. 


\section{Otherness in Academia}

Whilst insisting on the unique variation and intersectionality of oppressed identities, decolonial theorists embrace the convergence of struggles around the globe (Vergès, 2019) - including inside the Global North, where colonialist hierarchies give way to internal politics of race and ethnicity. Quijano (2007) suggests that, through European imperialism and global domination, Black/Brown became the colour of the dominated and White the colour of the dominant. Racial otherness inside the Global North thus entails specifically colonial socio-economic and political repercussions for individuals and groups. In line with this argument, we engage here primarily with ethno-racial otherness in the Global North. Rydgren (2007) highlights the salience of ethno-racial otherness where "the allocation of resources and rights - and risks - hinge [sic] on ethnic category belonging" (p. 227). Within academia, it has been suggested that, in order to discover the lived realities of the colonized subject inside the Global North, knowledge should be produced by researchers who have an intimate understanding of these lived realities. This has led to calls for minority perspectives in criminology (Phillips \& Bowling, 2003), such as feminist criminology (Gelsthorpe \& Morris, 1988), Black criminology (Russell, 1992; Young \& Sulton, 1991) or Arab criminology (Ouassini \& Ouassini, 2019).

While Phillips and Bowling (2003) suggest methodological, theoretical and ethical benefits will be gained from including minority perspectives, this thesis is not universally accepted. Howard Becker (1967) noted the hierarchies of credibility in the sociology of deviance, which are suspect of the objectivity of researchers who are too sympathetic towards their study 'subjects'. From a positivist point of view, the greater the distance between the researcher and the researched the better. The same philosophy privileges the technical expertise of system actors over the lived experience of system wards. Since the deviant and criminal object to be studied tends to be far from the academic White male on demographic and socio-economic spectra, the White researcher is presumed less biased - more so when he ascribes to positivist and empiricist traditions supposedly studying 'objective truths'. A logical conclusion of this belief is that the dearth of otherness among social science scholars is acceptable, if not, daresay, convenient or even desirable. Meanwhile, universalism and objectivism make researchers' otherness (or lack thereof) hard to reconcile as a matter of epistemological importance. 
Constructivist views emphasize the subjective nature of 'truth' and make an issue of the limited demographic standpoints represented in academia. Otherness is inherent in the colonised subject, the result of othering and "the consequence of racism, sexism, class (or a combination thereof) in terms of symbolic degradation as well as the process of identity formation related to this degradation" (Jensen, 2011, p. 65). The other is often constructed to help define a self (Gülerce, 2014; Morrison, 2017; Said, 1978). Colonialisms imagined the other in a reductionist and pathologizing way in order to construct a superior self: 'the oriental' is exoticized and fixed at a distance as alien for a European audience (Said, 1978), the 'African' becomes synonymous with "incomplete, mutilated, and unfinished" (Fanon, 1968; Mbembe, 2001) and the African American is constructed as particularly crime-prone (Covington, 1995). This is problematic for the colonized, who may experience ambivalence, uncertainty, the blurring of cultural boundaries between the inside and the outside (Dangaremba, 1989) - a cultural anomie which Fanon (1968) describes as a split existence and Du Bois (1903) as double consciousness.

The literature on otherness in criminology and criminal justice deals predominantly with criminal justice praxis and, to a lesser degree, the construction of the criminological other. Agozino notes that the criminological other (cf. also Garland, 2011) is frequently framed in racial terms based on a "widespread racist mythology among criminologists and criminal justice officials that black people in general and immigrants in particular are a crime-prone category of people" (Agozino, 2000, p. 360; see also Bull (2004) on 'Indigenous/Māori criminality'). As an expansion of orientalist thought, criminology depicts the other - non-White, nonEuropean subject - as inferior, dangerous, violent and amoral (Agozino, 2000; Bull, 2004; Kerboua, 2016; Said, 2003; Silva, 2018). Criminological scholarship offers little, however, regarding the role of otherness inside the system of knowledge production. If otherness is the dominant embodiment of the colonised subject in modern societies, then the othered lens may provide a useful prism to explore coloniality and imperialist reason within academia. In the present study, we explore this hypothesis. 


\section{Research Design}

\section{Collaborative Autoethnography}

Inspired by Gramsci's idea of 'knowing thyself' mentioned earlier, we use collaborative autoethnography to explore otherness. Autoethnographers study their life stories to reveal sociological phenomena at work within their own lived experiences (St. John et al., 2019). Self as subject offers advantages unavailable through other methodologies. Narrative theories of identity describe the life story through constructed narratives of a cohesive self (McAdams \& McLean, 2013). Typical methodologies capture only pieces of individual life narratives. In autoethnography, the full scope of perceived experience is accessible, including unflattering or taboo aspects typically edited in others' responses (Chang, 2016). Personal narratives reference dominant cultural narratives, either pulling from sanctioned templates (e.g., married by _, kids by __) or responding with alternatives (McLean et al., 2018). Studying an individual may reveal these larger narratives, but two researchers comparing two lives can more clearly gain insight into which aspects are distinct or shared.

Understanding narrative identity undergirds arguments by critical theorists across disciplines that the marginalized and othered have unique standpoints of epistemological and theoretical relevance (Ashlee et al., 2017; Harding, 2009). Othered experience is complex and difficult to capture in an hourlong interview or even over many years of recurring but impermanent cameos in an individual, group or culture's lifetime narrative. For this reason, critical theorists - especially critical race and, increasingly, decolonial theorists - have called for othered scholars to bring into full view treasures from the inner sanctum of their minds, that their secrets and their pain may enrich an otherwise whitewashed and incomplete historical record (Cann \& DeMeulenaere, 2012; Chawla \& Atay, 2018; Tsalach, 2013). As individuals inherently interested in the decolonization endeavour and intentionally committed to its agenda, our separate but common experiences of otherness provide meaningful insight for decolonial inquiry and practice.

Our study bridges the distance between analytic autoethnography and critical and decolonial perspectives. Original conceptions of analytic autoethnography critiqued the evocative sort in favour of the rigours and stylistic conventions of traditional qualitative research (Anderson, 2006). The dichotomy was false, as so-called evocative autoethnographers often 
already practised what was supposed to distinguish analytic autoethnography, including review of the established literature, structured analyses, data triangulation where possible, and post hoc academic (as opposed to purely narrative) voice (e.g., Ellis \& Rawicki, 2013). While not so dissimilar from several works classified as evocative, analytic autoethnography is clearly differentiated from creative works, like poetry or fictional storytelling (Vyran, 2006). Nevertheless, while adopting methods of rigour associated with mainstream analyses, we root our approach in philosophies of methods based in critical perspectives, including attention to the subjective nature of our truths, the many forms and sources of knowledge, the inability of our voice to speak for others, and vigilant scrutiny for biases and vestiges of colonial thinking in our analyses.

Most of our study material was generated through responses to a series of prompts, one each week over the course of four full weeks in February 2020. These prompts were original compositions, constructed through an iterative process in which we each proposed questions which animate our work (including this collaboration) and that inspire internal debate and struggle. We then negotiated which to include for a total of seven per prompt.iii Once finalized, prompts were stored and shared through cloudbased file-sharing services, namely Google Drive and Dropbox. During the first week in February, each author downloaded the assigned prompt for that week, wrote their response, and uploaded the response to the shared server. The next week, we repeated this process only, this time, also downloading our co-author's response from the previous week, to respond to each other's writing, adding a dialogic component to the work.

Each prompt began with instructions for us to write freely, "without polish and without restraint [...] as if you are talking to you[r] co-author". We wrote as much or as little as desired (unless specifically instructed otherwise) and could revise during a given week "though not after". Instructions were followed with questions serving multiple purposes. Some called for abstract self-reflection (e.g., "Have you read anything this week or had any experience that caused you to reflect on this work?") and others elicited biographical scenes (e.g., "Can you briefly describe [...] an instance when (a) ideological bias impacted you [...] ?”). Other prompts facilitated dialogue (e.g., "Read your co-author's responses from last week [dates inserted]. What reactions, if any, did you have to his writing?") and still others provoked self- and collaborative critique (e.g., "We both live in 
'Western' countries where our ethnic groups are not indigenous to this land - are we the colonized or colonizers?").

Importantly, we embraced Tillman-Healy's (2003) friendship-asmethod ethos, embarking on this study as part and parcel of our growing friendship. This facilitated openness and vulnerability, as well as 'comfort in challenge'. We could offer a more honest critique, as when Ahmed noted: "I thought your self-reflection really came through, although I sometimes felt like it did so too much; I sometimes get the impression that you are presenting in front of a big audience". We were more vulnerable, as in Kwan's response: "My current and impending careers require some discreetness here, the impact of which did not fully hit until I sat down to start [...]". We could elicit more from each other, as seen in Kwan's greater openness in responses thereafter. It also meant that dialogue meaningful to this work took place outside of scripted prompts, during evening conversations or WhatsApp messaging about contemporaneous experiences, updating each other on our goings-on and our external and internal reactions to them.

\section{Spanning Black- and Brownness}

Our narratives represent the unique and personal stories of individuals and cannot generalize to any of the groups to which we may belong. Still, people are a cacophony of group identities, and several of ours are part of the collective other within academia. Ahmed is an able-bodied, heterosexual, culturally Muslim, ethnic Arab Swiss male and Kwan is an able-bodied, homosexual, straight-presenting, liberal Christian, Black American male. Ahmed's research focuses on questions related to the (in)security of refugees, as well as politico-ideological mobilisation and violence, particularly in relation to causes and conflicts in the Arab World (Ajil, 2019, 2020). Kwan has focused most of his research on socio-psychological theories of identity and justice, often incorporating critical Black perspectives (Blount-Hill, 2020). We were advanced doctoral students in criminology and criminal justice at the time of the study. Our prompt responses revealed similar upbringings and parental influences. We strongly identify with our respective ethnic groups which we have both written about - Kwan has published on this subject using autoethnography previously (Blount-Hill \& St. John, 2017). 


\section{Data Analysis}

To analyse our collective stories, we collected all prompt responses into one document. Deleting the questions and prompts, we ended up with approximately 35,500 words of narrative. Each of us proceeded with open and axial coding of the entire material using both MAXQDA and pencilpaper. In line with traditional grounded theory, we pursued an exclusively inductive approach: we did not impose any pre-defined codes but allowed for codes and categories to emerge from the raw data (Birks \& Mills, 2015). We used coding memos to develop thoughts and ideas regarding codes and categories, and integrative memos to make connections with analytical concepts and the literature on decolonization and otherness (on memoing, see Walker \& Myrick, 2006). After coding individually, we compared our coding schemes and memos. Significant overlap in our core codes and classification of content led us to settle on three predominant themes throughout our material and across our separate narratives. After coding and adjustment, we exclusively used MAXQDA for data analysis. Using a code matrix, we identified frequently overlapping codes. A code map was used to explore proximity between codes and identify code clusters.

\section{Findings}

Our analyses revealed three primary dimensions of shared experience: (1) otherness as a lens to read coloniality, (2) feeling and coping with otherness, and (3) otherness as connection. The salience of these themes across our stories suggests otherness is a 'social fact' in the Durkheimian sense, i.e., a phenomenon involving representations and actions driven by forces largely external to individuals (Durkheim, 1895). Physical and cultural markers of ethno-racial difference, which comprise the major source of othering explored here, are not determined by individuals but rather imposed onto and into them, provoking processes of othering and reactions thereto ubiquitous and recurrent enough to be considered a social phenomenon having an existence of its own. The fact that social forces support structured hierarchies of the empowered and the dispossessed is a central theme of the decolonization literature. These forces - operating similarly within separate and distant life stories - construct a global narrative of physical and/or social exclusion and devaluation against which we struggle for an alternative. Where there was unity in our stories, it was borne of this common struggle. 


\section{Otherness as a Lens to Read Coloniality}

Our collaborative reflections revealed several instances in which - by virtue of our affiliation to a group or collective talked or written about as deviant or dangerous - we encountered dominant narratives whose assumptions did no justice to the nuanced lived reality of that group. Through the position of the othered, we viscerally and cognitively experienced the impact and symbolic violence of "being talked about" in ways that are simplistic, generalizing, exceptionalizing, exaggerating, and/or exoticizing. These dominant narratives revealed a patchwork of colonial legacies, where the other - Brown and Black people, in this instance - were ascribed characteristics positioning them as the uncontrolled (or uncontrollable) and, thus, legitimizing strategies of systemic and systematic control. The acceptance of reductionist assumptions about the other indicated hegemonic bias, wherein the narrator, usually speaking from a position of authority and respectability, accords greater weight to hegemonic narratives about others than to alternatives presented by the othered themselves. Our experience further suggests a status-quo bias toward definitions and theses sympathetic to the state and criminal justice institutions. The use of statusquo hegemonically-biased dominant narratives uncritically attributes axiomatic legitimacy to entities whose interest is in maintaining a status quo. Kwan described his participation in a discussion about the implications of recent reductions in arrests for minor offences within a local jurisdiction. His narrative highlighted an instantiation of the predominant 'default' position assuming systemic benevolence:

The heat in the conversation came at the point where an outside advisor, but the "authority in the room," pitched them as a notable achievement for Black residents and that we should trumpet the results specifically as an achievement in racial progress. I recall being the first hand that went up, noting that our reductions in these detentions were premised on the recognition that its previous punishment via incarceration had always been too harsh and that it seemed unreasonable to pitch this as anything more than government correcting a wrong it had created (in the spirit of solemn regret and repentance), not as a celebration of government's leniency and care (with a spirit of celebration and benevolence). 
However, analysis of overlapping frequencies in our coding revealed connections between our identifications of hegemonic and status-quo bias and realizing evidence of our own and minority others' 'colonized minds'. In several cases (e.g., writing on 'radicalized' females in Ahmed's case and on Islamist 'terrorists' in Kwan's) we, ourselves, had propagated hegemonic and status-quo bias and uncritically adopted assumptions and theses postulated by dominant narratives. Engaging retrospectively with these works with greater attention to bias and coloniality revealed, in sometimes disturbing ways, how we had been oblivious to our own enactments of symbolic violence. With respect to other individuals, we noted instances where individuals sharing our othered traits adopt - wittingly or unwittingly - a colonial hegemonic narrative. Using the language of the time, Malcolm X characterized these as manifestations of a 'house negro' mentality, a phenomenon also described by Fanon's (1968) notion of Black Skin, White Masks or Dabashi's (2011) 'house Muslim' (Brown skin, White masks). The latter can be seen in Ahmed's description of a workshop on responses to terrorism that he gave to a group of French police officers:

During the workshop, it was very clear that many shortcuts and stereotypes about terrorism and Muslims were hanging heavily in the room. I was trying to respond to the often very problematic comments in the most thoughtful way possible, which was challenging. In that environment, dominated by an Islamophobic narrative, there was one guy of North African Arab descent who perfectly incarnated the figure of the 'house Muslim'. His statements focused on vilifying Salafists in France, in order, it seemed, to purify his image and make clear who he was (not a traitor, but an ally in the fight against terrorism, trying to prove his loyalty). He described his patrol tactics in public transport: "I will tell you honestly, I do racial profiling. I speak Arabic, but I hide it. I stand close to Arabs and listen to what they are saying. When I hear suspicious things, I control them. For example, when they say something about police officers. The guy with a long beard, I check him."

In short, we found that our otherness helped make us sensitive to othering discourse within dominant narratives and to identify when others or we, ourselves, relied on these narratives to describe the other. Important 
to this study, however, was the commonality between our experiences. Set on opposite sides of an ocean and in very different contexts, our shared experience revealed not the presence of dominant narratives but of one dominant narrative - the story of a prototypical 'good guy' with 'good values' from 'good people' struggling against the barbarity of the other. On this point, the singularity of our otherwise distinct life stories was glaring.

\section{Feeling and Coping with Otherness}

While otherness helps as a lens to read coloniality, it also leads to feelings of frustration and helplessness. Our analysis suggested the 'subtlety problem' as a primary cause: while we viscerally experience instances of othering, it is often difficult to pinpoint clear and unequivocal problems in interpersonal interactions and system processes. Narratives being a complex assemblage of ideas and assumptions of which many may be unproblematic, it is often difficult to dissect where symbolic violence is present, let alone to analyse it, describe it and communicate it convincingly.

Despite the ambiguousness surrounding it, feeling othered manifests itself both cognitively and emotionally, buoyed by a recurrent nature that makes it impossible to dismiss. These feelings include those of unbelonging and illegitimacy, which work together to convey the impression that one's voice or contribution may be less valued because one is the other. Our own reflections reveal this especially in the many situations where our groups are objects of discussion on topics like Black delinquency or Jihadist violence. Our perceived proximity to the groups and individuals targeted by the debate becomes a predicament to our academic credibility, as seen in Ahmed's following experience after a presentation of his research:

After a talk, I was approached by a colleague who opined that I should look more seriously into Islam as a cause of terrorism. He suggested I'd consult the views of Sam Harris and an ExMuslim woman (who had suffered immensely in an oppressive fundamentalist family with links to Al-Qaeda). I do, in fact, look into how ideologies and narratives inspired by religious ideas play a role in this phenomenon, but my findings point to the importance of socio-/geopolitical and structural aspects. But his insistence and lack of listening demonstrated his assumption that I was biased, for reasons not stated explicitly but hardly untied from my cultural-ethnic background. 
Throughout, he kept smiling and hiding behind a veil of empiricist evidence (e.g., "in my class on terrorism, I learned that there is empirical evidence linking terrorism to religiosity").

The emotional impacts of being othered in these contexts include indignation, destabilization, and frustration (especially, considering the subtlety problem mentioned earlier). What seems to be particularly paralysing about such situations is the unchallenged power of an oppressive dominant narrative. Respected subject matter experts easily shroud unjustified and marginalizing propaganda in the veneer of empiricist evidence (often biased and incomplete), intentionally or naively oblivious to their complicity in the symbolic violence of their statements. As a result, it becomes challenging to communicate the problematic nature of their posture.

Otherness and the social and professional interactions it provokes can be dealt with, of course, in a plethora of ways. We found there to be commonalities between our experiences. One way we engage with otherness is through emotional self-policing to avoid being perceived as self-victimising or defensive. This manifests itself in both short-term tactical and long-term strategic decisions. The former includes avoiding certain statements or selectively problematizing aspects of an issue related to othering, as illustrated in Kwan's disagreement with a fellow criminal justice researcher before a policymaking audience:

\begin{abstract}
I declined to attack the ideology of Black criminality and police saviorism implicit in [the researcher's presentation] but instead chose to point out the several points of disqualifying technical and conceptual flaws. My critique was followed by several Black practitioners in the room who more explicitly pointed out the racial bias in his assumptions and used the technical flaws I had pointed out to frame this as a presentation based in racial ideology, not science.
\end{abstract}

The long-term impact concerns strategic choices of programmes, universities, political engagement, or even theoretical frameworks to avoid being easily put into the category of the 'complaining other'. Both Kwan and Ahmed expressed a struggle in seeking legitimacy and proving their worth in ways that minimized their otherness: 
I encountered legitimacy theory and was intrigued and enthralled by a psychological framework that offered some promise in framing what I felt toward legal authority as a Black man in language that sounded technical and expert, not dismissible as Black complaining. (Kwan)

I had been raised on the premise that focusing on systems and dynamics of oppression (that I, myself, am subjected to) equates to self-victimisation. Undeniably, this was part of my parents' noble aspiration to provide me with the tools to excel as an outsider, a son of refugees. However, it made me oblivious to dynamics and power structures that I was perhaps able to deal with in a positive manner, but which others were undeservedly struggling with. (Ahmed)

A prominent long-term strategy, tied by both of us to parental influences, was a preoccupation with outperforming expectations and going above and beyond the accomplishments of others. On the one hand, this has to do with the pragmatic realisation that otherness is often linked to several handicaps, including lower socio-economic status or cultural-linguistic difference. Still, outperforming is not only an attempt to compensate for these handicaps in our pursuit of professional success but also a way of countering stereotypes associated with our respective reference groups, such as intellectual or cultural inferiority. On the other hand, we wrote not only of the privilege that comes with success but also the fact that we may be construed as exceptions to the norm, held up as examples of "how you can succeed". Success made us vulnerable to tokenisation and therefore complicit in justifying a system that maintains its alienating essence [cf. house negro/Muslim].

A sense of responsibility to uplift those left behind, marginalised and oppressed was evident in our life stories. We both noted parental influence as critical in this regard. We admire individuals who dedicate their lives to the fight against oppression and for social justice. In our own professional strivings, we acknowledged our inescapable representativity, knowing that our individual actions tend to be constructed as representative of our most apparent reference groups. Kwan recognizes as much when writing of connecting with a Black colleague: 
We began our relationship early on with a discussion about how important it was for us to both succeed in our respective positions as (unfortunately) we would inevitably be seen as 'representative' of the capability of all Blacks.

At the core, a predominant theme in our reflections was the struggle to maintain a professional pursuit inside a system we are critical of but must excel in to reform it and advance our emancipatory aspirations. In a knowledge production industry that is complicit in the epistemic and political oppression of others, otherness comes with feelings of guilt and anxiety: guilty for benefitting in various ways from the system and anxious not to become too complicit in it. Guilt also because of a contradiction in our narratives around emancipatory struggle and the objective privilege of a comfortable lifestyle as a result of our professional pursuits. Managing this conflict requires a considerable amount of cognitive and emotional effort. In this struggle, we found the third dimension in our stories of otherness to be critical.

\section{Otherness as Connection}

Accepting our constructed positions as representatives of our respective reference groups can be detrimental to how we engage with other individuals associated with these groups and with others more generally. Perceived ramifications of individual actions for entire collectives cause us to often hold others to a very high standard. This leads to unease around members of our reference group that we saw as acting or speaking in ways that unfortunately confirm certain stereotypes. We have no right to judge, of course, but these reactions were nonetheless common in our narratives. The other (more positive) side of this coin is otherness pride - a sense of enthusiasm and enthrallment at an other's excellence.

Still, more often, otherness connects. In a professional world, where otherness is by definition marginal, there exists a form of solidarity and understanding between individuals who feel othered. On a personal level, this can help to feel heard, share the weight of struggle, and not feel alone. The presence of others in a space where a dominant narrative prevails can encourage and empower those who might otherwise allow their critical voices to be silenced. We saw that intentionally seeking out others has become a strategy for both of us, though still maintaining connections with individuals more closely aligned with mainstream narratives and hegemonic discourse. 
Creating a network of individuals who share personal and professional experiences and who may care about similar causes has proved to be beneficial for both of us and for our respective projects (the present collaboration bears witness thereto). Importantly, 'otherness solidarity' or perceived 'unity in struggle' leads us to identify with oppressed and marginalised groups beyond our immediate reference group and leads us to align the visions we have for our careers and our lives more generally.

In academia specifically, our analysis suggests that otherness is an attribute that can be put in the service of intellectual depth and strong ethics. In our experience, researchers who have a first-hand understanding of the symbolic violence of othering and a certain grasp for how hegemonic discourse can support and cement systems and dynamics of oppression, tend to approach research more carefully, humbly, and with a concern for the delicate handling of the power of knowledge. Otherness in race, sex, ability, faith, etcetera, seems to lend a sort of sensitivity or carefulness in the way research is conducted, data is analysed and results are presented. Encountering hegemonic bias often positioned as 'universal knowledge', such researchers more readily point out the subjectivity of truth and holes in the veil of empiricist objectivism. More often, they seem to think about the larger symbolic, social and political ramifications of their research.

\section{Concluding Remarks}

Throughout our collaboration on this project, we realised that the process from data collection to manuscript writing and all our accompanying discussions are part of a decolonising endeavour. The autoethnographic process as a tool has indeed felt emancipatory to both of us and we encourage other researchers, especially those presenting intersectional attributes of otherness, to pursue this work. Not only could the multiplication of such works contribute to our personal and professional development but may also allow us to collectively imagine ways to realise the emancipatory and decolonising potential of 'insider insights' (Denzin \& Lincoln, 2008, p. ix). This endeavour, as Keet (2014) cogently puts it, will require both "academic resources and political courage" (p. 35).

Based on our work, we propose three major dimensions of otherness as a social fact. First, we found otherness to be a lens through which coloniality can be read as it manifests itself in dominant narratives rife with hegemonic and status-quo bias. Othered individuals, especially when they 
have a close understanding of the groups and collectives targeted by a particular debate, may more naturally discern the symbolic violence of 'being talked about' in both emotional and cognitive terms. In turn, critical sensitivity to othering processes may make the colonised subject more apt to discover when oneself or others adopt the hegemonic narrative. Second, we have identified shared ways of reacting to otherness. Coping mechanisms include emotional self-policing to avoid being perceived as 'complaining' or 'self-victimising' and a commitment to outperforming. Importantly, a prevailing theme in our narratives was the struggle to reconcile aspirations of excellence inside an oppressive system with the pursuit of radical emancipatory projects which meant to challenge that system. Finally, an important dimension is the potential of otherness to connect individuals commonly affected by it. Otherness solidarity contributes to creating safe spaces where a hegemonic narrative is dominant as well as to the reimagination of seemingly localised and individual struggles as forming part of a more global struggle against the legacies and current repercussions of colonial and imperialist reason. The feeling resonates with a phrase that is frequently attributed to Aimé Césaire's: Je suis de la race de ceux qu'on opprime (I am of the race of those who are oppressed).

In conclusion, the most important contribution of otherness to the academic realm may be of epistemological and methodological nature. As Kitossa (2012) noted, othered researchers tend to adopt more critical postures inside academia, which question traditional aspects of knowledge production. Our narratives support this claim and we would encourage further (e.g. quantitative) inquiry into this important hypothesis. When it comes to fieldwork and analysis, we suggest that the personal experience of being othered can be crucial. Whether for their own group(s) or other othered, researchers with an "othered lens" can put their unique positionality and sensitivity - if well-worked and reflected upon - at the service of their fieldwork to produce knowledge that carefully considers the symbolic and discursive violence that may come with 'talking about others', but also the tangible social and political ramifications of their findings. In line with preceding scholars (Cunneen \& Rowe, 2014; Deckert, 2017; Garcia, 2018; Mills, Massoumi \& Miller, 2019; Tauri, 2017), we suggest moving towards ethical guidelines for the conduct of research that do justice to the complexity of writing 'the other' and the potential of doing so 'as other' (Keet, 2014). 


\section{References}

Aas, K. F. (2012). 'The earth is one but the world is not': Criminological theory and its geopolitical divisions. Theoretical Criminology, 16(1), 520.

Agozino, B. (2004). Imperialism, crime and criminology: Towards the decolonisation of criminology. Crime, Law and Social Change, 41(4), 343-358.

Agozino, B. (2003). Counter-colonial criminology: A critique of imperialist reason. London, UK: Pluto Press.

Agozino, B. (2000). Theorizing otherness, the war on drugs and incarceration. Theoretical Criminology, 4(3), 359-376.

Ajil, A. (2020). Politico-ideological violence: Zooming in on grievances. European Journal of Criminology, Online First, 1-18. DOI:10.1177/1477370819896223

Ajil, A. (2019). Leaving peace for war: An exploratory study of Swiss men's trajectories toward engagement in Arab conflicts. Sozialpolitik.ch, 2(3).

Al-Kassimi, K. (2018). ALBA: A decolonial delinking performance towards (Western) modernity - An alternative to development project. Cogent Social Sciences, 4(1), 1-35.

Anderson, L. (2006). Analytic autoethnography. Journal of Contemporary Ethnography, 35(4), 373-395.

Arday, J., \& Mirza, H. S. (Eds.) (2018). Dismantling race in higher education: Racism, whiteness and decolonising the academy. London, UK: Springer.

Ashlee, A. A., Zamora, B., \& Karikari, S. N. (2017). We are woke: A collaborative critical autoethnography of three "womxn" of color graduate students in higher education. International Journal of Multicultural Education, 19(1), 89-104.

Becker, H. S. (1967). Whose side are we on? Social problems, 14(3), 239-247.

Belknap, J. (2015). Activist criminology: Criminologists' responsibility to advocate for social and legal justice. Criminology, 53(1), 1-22.

Birks, M., \& Mills, J. (2015). Grounded theory: A practical guide. London, UK: Sage.

Blount-Hill, K. (2020). Advancing a social identity model of system attitudes. International Annals of Criminology, Online First. DOI:10.1017/cri.2020.8 
Blount-Hill, K. (2019). Post-colonial criminology. In F. P. Bernat, K. Frailing, L. Gelsthorpe, S. Kethineni, \& L. Pasko (Eds.), Encyclopedia of women and crime. Hoboken, NJ: John Wiley \& Sons.

Blount-Hill, K., \& St. John, V. (2017). Manufactured 'mismatch': Cultural incongruence and Black experience in the academy. Race and Justice, $7(2), 110-126$.

Bull, S. (2004). 'The land of murder, cannibalism, and all kinds of atrocious crimes?': Maori and crime in New Zealand, 1853-1919. British Journal of Criminology, 44(4), 496-519.

Cain, M. (2000). Orientalism, occidentalism and the sociology of crime. British Journal of Criminology, 4O(2), 239-260.

Cann, C. N., \& DeMeulenaere, E. J. (2012). Critical co-constructed autoethnography. Cultural Studies $\leftrightarrow$ Critical Methodologies, 12(2), 146-158.

Chang, H. (2016). Autoethnography in health research: Growing pains? Qualitative Health Research, 26(4), 443-451.

Chawla, D., \& Atay, A. (2018). Introduction: Decolonizing autoethnography. Cultural Studies $\leftrightarrow$ Critical Methodologies, 18(1), 3-8.

Covington, J. (1995). Racial classification in criminology: The reproduction of racialized crime. Sociological Forum, 10(4), 547-568.

Cunneen, C. (2011). Postcolonial perspectives for criminology. In M. Bosworth \& C. Hoyle (Eds.), What is criminology? (pp. 249-266). Oxford, UK: Oxford University Press.

Cunneen, C. (1999). Criminology, genocide and the forced removal of Indigenous children from their families. Australian \& New Zealand Journal of Criminology, 32(2), 124-138.

Cunneen, C. \& Rowe, S. (2014). Changing narratives: Colonised peoples, criminology and social work. International Journal for Crime, Justice and Social Democracy, 3(1), 49-67.

Dabashi, H. (2011). Brown skin, White masks. London, UK: Pluto.

Dangarembga, T. (1989). Nervous conditions. Seattle, WA: Seal Press.

Deckert, A. (2017). A level playing field: Conceptualizing an empowering research framework for criminologists who engage with marginalized communities. Critical Criminology, 25(4), 559-575.

Deckert, A. (2014). Neo-colonial criminology: Quantifying silence. African Journal of Criminology and Justice Studies, 8(1), 39-63. 
Denzin, N. K. \& Lincoln, Y. S. (2008). Introduction. In N. K. Denzin, Y. S. Lincoln and L. T. Smith (Eds.), Handbook of critical and Indigenous methodologies (pp. ix-20). London, UK: Sage.

Du Bois, W. E. B. (2006/1903). The souls of black folk. University Park, PA: Pennsylvania State University.

Durkheim, E. (2017/1895). Qu'est-ce qu'un fait social? In Les règles de la méthode scientifique. Paris, France: Flammarion.

Ellis, C., \& Rawicki, J. (2013). Collaborative witnessing of survival during the Holocaust: An exemplar of relational autoethnography. Qualitative Inquiry, 19(5), 366-380.

Fanon, F. (1968). The wretched of the earth. New York, NY: Grove Press.

Foucault, M. (1980). Power/knowledge: Selected interviews and other writings 1972-1977, edited by C. Gordon. New York, NY: Pantheon.

Garcia, G. A. (2018). Decolonizing Hispanic-serving institutions: A framework for organizing. Journal of Hispanic Higher Education, 17(2), 132-147.

Garland, D. (2011). Criminology's place in the academic field. In M. Bosworth \& C. Hoyle (Eds.) What is Criminology? (pp. 298-317). Oxford, UK: Oxford University Press.

Gelsthorpe, L., \& Morris, A. (1988). Feminism and criminology in Britain. The British Journal of Criminology, 28(2), 93-110.

Gramsci, A. (1971) Selections from the prison notebooks of Antonio Gramsci, edited and translated by Q. Hoare \& G. N. Smith. New York, NY: International Publishers.

Gülerce, A. (2014). Selfing as, with, and without othering: Dialogical (im)possibilities with dialogical self theory. Culture \& Psychology, 20(2), 244-255.

Hall, S. (1997). The work of presentation. In S. Hall (Ed.) Cultural representations and signifying practices (Vol. 2) (pp. 15-61). London, UK: Sage.

Harding, S. (2009). Standpoint theories: Productively controversial. Hypatia, 24(4), 192-200.

Hinton-Smith, T. (Ed.). (2012). Widening participation in higher education: casting the net wide? London, UK: Palgrave Macmillan.

Jensen, S. Q. (2011). Othering, identity formation and agency. Qualitative studies, 2(2), 63-78.

Keet, A. (2014). Epistemic 'othering' and the decolonisation of knowledge. Africa Insight, 44(1), 23-37. 
Kerboua, S. (2016). From orientalism to neo-orientalism: Early and contemporary constructions of Islam and the Muslim world. Intellectual Discourse, 24(1), 7-34.

Kitossa, T. (2012). Criminology and colonialism: Counter colonial criminology and the Canadian context. The Journal of Pan African Studies, 4(10), 204-226.

Mbembe, A. (2001). On the postcolony. Berkley, CA: University of California Press.

McAdams, D. P., \& McLean, K. C. (2013). Narrative identity. Current Directions in Psychological Science, 22(3), 233-238.

McLean, K. C., Lilgendahl, J. P., Fordham, C., Alpert, E., Marsden, E., Szymanowski, K., \& McAdams, D. P. (2018). Identity development in cultural context: The role of deviating from master narratives. Journal of Personality, 86(4), 631-651.

Mignolo, W. (2011). The darker side of Western modernity: Global futures, decolonial options. Durham, UK: Duke University Press.

Mignolo, W. (2005). The idea of Latin America. Malden, MA: Blackwell Pub.

Mills, T., Massoumi, N., \& Miller, D. (2019). The ethics of researching 'terrorism' and political violence: A sociological approach. Contemporary Social Science, 15(2), 119-133.

Moosavi, L. (2018). Decolonising criminology: Syed Hussein Alatas on crimes of the powerful. Critical Criminology, 27(2), 229-242.

Morrison, T. (2017). The origin of others. Boston, MA: Harvard University Press.

Ouassini, N., \& Ouassini, A. (2019). Criminology in the Arab world: Misconceptions, nuances and future prospects. The British Journal of Criminology, 60(3), 519-536.

Phillips, C., \& Bowling, B. (2003). Racism, ethnicity and criminology. Developing minority perspectives. British Journal of Criminology, 43(2), 269-290.

Quijano, A. (2007). Coloniality and modernity/rationality. Cultural Studies, 21(2/3), 168-178.

Russell, K. K. (1992). Development of a Black criminology and the role of the Black criminologist. Justice Quarterly, 9(4), 667-683.

Rydgren, J. (2007). The power of the past: A contribution to a cognitive sociology of ethnic conflict. Sociological Theory, 25(3), 225-244.

Said, E. (1978). Orientalism. New York, NY: Random House. 
Silva, D. M. (2018). Radicalisation: The journey of a concept, revisited. Race \& Class, 59(4), 34-53.

St. John, V. J., Blount-Hill, K., Evans, D., Ayers, D., \& Allard, S. (2019). Architecture and correctional services: A facilities approach to treatment. The Prison Journal, 99(6), 748-770.

Stockdale, K., \& Sweeney, R. (2019). Exploring the criminology curriculum. In Papers from the British Criminology Conference, An Online Journal by the British Society of Criminology (pp. 84-105).

Takagi, P. (1981). Race, Crime, and Social Policy: A minority perspective. Crime and Delinquency, 27(1), 48-63.

Tatum, B. L. (2000). Toward a neocolonial model of adolescent crime and violence. Journal of Contemporary Criminal Justice, 16(2), 157-170.

Tauri, J. M. (2017). Imagining an Indigenous criminological future. In A. Deckert \& R. Sarre (Eds.) The Palgrave Handbook of Australian and New Zealand Criminology, Crime and Justice (pp. 769-783). Cham, Switzerland: Springer.

Tauri, J. M. (2012). Indigenous critique of Authoritarian criminology in Australasia. In K. Carrington, M. Ball, E. O’Brien, \& J. M. Tauri (Eds.), Crime, justice and social democracy: International perspectives ( $\mathrm{pp}$. 217-233). London: Palgrave Macmillan.

Tillman-Healy, L. M. (2003). Friendship as method. Qualitative Inquiry, 9(5), 729-749.

Tsalach, C. (2013). Between silence and speech: Autoethnography as an otherness-resisting practice. Qualitative Inquiry, 19(2), 71-80.

Vèrges, F. (2019). Un féminisme décolonial. Paris, France : La Fabrique.

Vryan, K. D. (2006). Expanding analytic autoethnography and enhancing its potential. Journal of Contemporary Ethnography, 35(4), 405-409.

Wa Thiong'o, N. (1992/1986). Decolonising the mind: The politics of language in African literature. Nairobi, Kenya: East African Educational Publishers.

Walker, D., \& Myrick, F. (2006). Grounded theory: An exploration of process and procedure. Qualitative Health Research, 16(4), 547-559.

Young, V., \& Sulton, A. T. (1991). Excluded: The current status of AfricanAmerican scholars in the field of criminology and criminal justice. Journal of Research in Crime and Delinquency, 28(1), 101-116.

X., M. (1990). Malcolm X speaks: Selected speeches and statements. New York, NY: Grove Press. 


\section{Endnotes}

i A thorough discussion of the meaning of power is beyond the scope of this paper. We draw on the Foucauldian notion of knowledge/power, since we are discussing the role of Western academia.

ii We acknowledge that the period of European global colonization of which we speak is, by no means, the only example of colonization and, in fact, peoples of colour have engaged in colonial practices. That said, European global colonization is distinguished, inter alia, by its global scope, worldwide dominance and enduring legacy.

iii Prompts are available upon request. 
